\title{
Fleeting Substantiality: The Samoan \\ Giant in US Popular Discourse
}

\section{April K Henderson}

\section{$\mathrm{I}_{\mathrm{n}}$}

friend's high school classroom at a juvenile justice facility in the San Francisco Bay Area. My presentations covered very general aspects of Pacific Islands history, politics, and culture and concluded with some comments on an enduring research specialty of mine, Samoan involvement in hip hop music, dance, and visual art. The students-three separate classes of ten to fifteen teenagers-were primarily male save for three young women, appeared to be mostly African American and Latino with perhaps two white males and two Asian males, and were all residents of the facility. Most had little or no knowledge of the geography or history of various Pacific Islands, yet they expressed strikingly consistent estimations of the Pacific Islanders who shared the urban geography of their own Bay Area communities. This became apparent after I commenced each presentation with a simple introductory exercise.

For each class, I wrote "Pacific Islands," "Hawai'i," "Sāmoa/Samoans," and "Tonga/Tongans" on the blackboard and asked students to write their own word associations for these terms on index cards. Admittedly, my words were not precisely analogous; as it was, the associations they gave for "Pacific Islands" and "Hawai' $i$ " primarily engaged the Islands as sites, while their word associations for "Sāmoa/Samoans" and "Tonga/ Tongans" focused on the second portion of those word pairs and engaged Samoans and Tongans as peoples. What became clear, perhaps owing to my inadvertent oversight in creating the categories, were the remarkable differences between how students viewed Islands and how they viewed Islanders.

"Hawai'i," an island site overwhelmingly framed by touristic representation, garnered the expected gendered results: "islands with girls with trees for skirts"; "girls, bikinis, beach, booty, thongs, water, palm trees";

The Contemporary Pacific, Volume 23, Number 2, 269-302

(C) 201 I by University of Hawai'i Press 
"wemon [sic]"; "beautiful"; and the predictable "paradise." The phrase "Pacific Islands," probably less evocative for US adolescents than the alternative phrase "South Pacific," reaped fewer responses. Students primarily cited names of island groups ("Hawai'i"; "Samoa"; "Tonga"; "Phillipens [sic]") or terms similar to those accrued to the word "Hawaici": "girls, culture, people, food"; "partying, beaches"; "surfing"; "hot, sunny." There was a consistent tendency to associate the Islands with far-off, idealized places-places of leisure that, for the young men in the classes, was inextricably associated with the bountiful presence of "girls" and "wemon [sic]." The Islands were heavily feminized in representation, in ways that are familiar to scholars of the region who critique the work such representations do to both obscure and underpin gendered and geopolitical power imbalances: "situated at the top of a racial and cultural hierarchy of Pacific Islands natives," Teresia Teaiwa has argued, the invariably Polynesian body of the dusky maiden "is given the privilege of representing the Pacific as a whole" (Teaiwa I999, 254). The iconic swaying hula girl image renders invisible millions of women from the western Pacific who don't match the idealized Polynesian type, but her exposed flesh and come-hither invitations also conceal histories of exploitation and resistance across the Pacific, including those of Polynesia (Jolly 1997, 2007; Teaiwa 1994; Tcherkézoff 2003; Trask 1993).

Responses to the other terms in my word association exercise, however, were rather different from this familiar gendered iconography. For "Sāmoa/Samoans," students wrote: "big people"; "Bloods, Crips, savages, violent, crazy, big"; "big, buff, Crypts [sic], 30's, P.C.G., T.C.G."; "big people"; and "big fat people, gangs." For "Tonga/Tongans": "big people"; "biger [sic] people"; "tough, vilant [sic]"; "large people"; "big families"; "Bloods, Crips, big"; "Crips"; and "big muscle people, gangs." Recurrent in these terms was the linking of Samoans and Tongans to gangs both generally and specifically, as the recitation of particular gang sets (Bloods, Crips, T.c.G.) or gang-claimed urban blocks (30's) attests. Also appearing again and again were value-laden references to toughness, violence, and most common of all physical size.

In the United States, popular narratives about Samoan size, strength, and fierceness are certainly not exclusive to the corrections system; they cycle through broader avenues of popular discourse and are immediately familiar to researchers working in and with Samoan communities. Anthropological work frequently notes these stereotypes but often avoids dwelling on them, in an effort to illuminate complex cultural processes 
within communities rather than rehash the expectations foisted on them by outsiders. Public representations of Samoans and other Pacific Islanders in the United States have nevertheless been a source of concern for researchers for quite some time, as evidenced by the 1978 call for a study on the topic from anthropologist Bradd Shore. Speaking in California at a roundtable of academics and community members meeting to discuss Pacific Islander migrant issues, Shore elaborated that a study should not just identify popular representations of Samoans and other Pacific Islanders in the United States, but also examine "how they get that image-on what basis is it formed? What are the channels through which stereotypes are communicated?" (Macpherson and others I978, 83).

Some three decades later, these questions are still necessary. Public mythology about Samoans is, as the saying goes, the giant in the roomeverybody knows it's there but it's so ubiquitous as to go unexamined. How are Samoans being imagined in the United States? What types of representations are sedimenting in American public discourse to produce a popular image of a population that the vast majority of Americans know very little about? How are representations gendered in particular ways, such that the archetypal Samoan body in US popular discourse is now masculine, rather than feminine? How are representations of Samoan men similar to representations of black men-the latter so central to discourses of race in the United States? In what ways are they different? To understand the discursive terrain that Samoans negotiate in the United States, active processes of representation-what I venture to call myth creationmust be exposed, engaged, and examined.

This article draws examples from the broader terrain of popular and academic discourse to explore the gendered and spatialized dimensions of a shift in representation-a marked contrast between how many Americans imagine Pacific Islanders to be in the Islands and how they imagine them to be in the United States. It offers a particular kind of addition to a developing body of literature on Pacific masculinities. It springs from over a decade of ethnographically informed work among Samoan men and women involved in hip hop culture (Henderson I999, 2006, 2007), but unlike the bulk of that work, actual Samoans are not at the center of this essay. Although Samoan voices appear occasionally, the primary objective here is to map the discursive terrain-the realm of representation, of popular myth making - that those actual Samoans navigate in the United States. This, in a sense, is the essay that had to be written in order to get on with the rest of my work. 


\section{Mythogenesis}

In a 1994 publication accompanying a major US art exhibition exploring representations of black men, cultural historian Clyde Taylor wrote, "Black men are densely mythogenic, the object of layered fictions produced by others. Like other mythogenic people-Gypsies, Jews-the legend of the black man outruns and awaits him through the course of his journey" (1994, I69). Emphasizing the "costly centrality" of black male mythography to American life, Taylor quoted Ralph Ellison to imagine "the whole of American life as a drama acted out upon the body of a Negro giant, who, lying trussed up like Gulliver, forms the stage and scene upon which and in which the action unfolds" (Ellison 1964, 46, quoted in C Taylor 1994, I67). The complete absence of Native American land and bodies in Ellison's metaphor begs questions, but Taylor did not ask them; the indigenous presence once so central to American imaginaries of citizenship and nationhood (Deloria 1999) has been eclipsed by popular discourses foregrounding blacks as the preeminent domestic Other.

I'd like to utilize Taylor's terminology to ponder the representational work occurring in my opening anecdote, where several classrooms of students whose own ethnicities are "densely mythogenic" in ways quite central to narratives of race and national belonging in the United States are actively recounting and constructing myths of another, more recent American population. This is mythogenesis in action. If myths about black men are the weft of American life, myths about Samoan men are, as yet, sparser strands more locally concentrated in the urban neighborhoods of western US cities like Los Angeles, San Francisco, San Diego, Salt Lake City, Las Vegas, Seattle, Honolulu, and Anchorage-still nascent at the national level but slowly disseminating through popular media and those great vehicles of American male mythogenesis, the National Football League and the theatrical sport of professional wrestling.

Contemporary cultural studies work has long examined the production and sedimentation of popular mythologies. By mythology, I mean the naturalization of presentations of how things are and how things should be, such that the histories and machinations of social relations and power relationships are obscured, and alternative presentations are foreclosed. Roland Barthes's foundational and oft-cited 1957 book Mythologies is a particularly obvious reference point in this conceptual terrain. Describing his motivation in writing that text, Barthes observed, "I resented seeing Nature and History confused at every turn, and I wanted to track down, 
in the decorative display of what-goes-without-saying, the ideological abuse which, in my view, is hidden there" (I972, II; italics in original). Relevant also is the influential 1978 volume Policing the Crisis, in which Stuart Hall and his colleagues from the Centre for Contemporary Cultural Studies examined the trajectory of "mugging" in I970s Britain, exploring how the term was imported from the United States already embedded in a "referential context"-enmeshed in social imaginaries of aggressive, black, criminal strangers and hapless white victims. The work of such imaginaries-the material effects of public belief in mugging as a new, dangerous threat to the security of good citizens-was the authorization of increasingly repressive police and juridical procedures that exacted ever more punitive measures on young black men (Hall and others 1978). If we utilize Hall and his coauthors' terminology to ask, "What is the referential context for Samoans in the United States?" or Barthes's phrase to ask, "What goes without saying when people talk about Samoans?" the distressing answer is at least in part suggested by the anecdote that opened this essay.

The critical cultural studies projects of Stuart Hall and his compatriots were importantly shaped by Gramscian delineations of ideology, hegemony, and common sense (Gramsci I97I, I985). Antonio Gramsci's work continues to enjoy wide readership; one notable reason is that his contributions to Marxist thought took culture seriously. Gramsci understood the terrain of culture-and particularly popular culture and the arts-as a contested site where hegemonic forces fight for, coerce, or seduce the consent of the masses. Contrary to misinterpretations of Gramscian hegemony that would understand it as about outright oppression or forceful subjugation, Chandra Mukerji and Michael Schudson explained, "Gramsci held that, in fact, oppressed groups accept the definition of the world of elites as common sense; their understanding of how the world works, then, leads them to collaborate in their own oppression" (I99I, I 5). By highlighting people's ambivalent investments in popular mythologies about themselves, this essay raises the vexed question of such collaboration. The very conception of the terrain of culture as contested, however, suggests that it can also be a site for resistance and for the shaping of alternative ideologies. Indeed, this is the hope that fuels most critical cultural studies scholarship.

Of course, no discussion of how mythologies of the Other are produced-and the work such mythologies enable-would be complete without noting also the profound influence of Edward Said's Orientalism 
(1978). Said's work has substantially informed critical scholarship on public mythologies about Pacific Island places and peoples: Greg Fry's stringent critiques of Australian technocratic renderings of the Pacificand the foreign policy fueled by such representations-are but one salient example (Fry 2000). It is imperative to remember, however, as Subramani has reminded us, that "the important work of dismantling orientalism had begun in the [Pacific] region some time before Edward Said put a name to it" (Subramani 200I, I50-I5I), with Albert Wendt, among others, critiquing the legacy of colonial representation in essays and fiction (Wendt I973, I976).

Closer to the particularly gendered stakes of this essay, Pacific feminist theory has long exposed and challenged links between representations of Pacific women and processes of colonial exploitation of land, resources, and people. The works of Teresia Teaiwa and Haunani-Kay Trask are obvious examples, while scholars such as Claire Slatter and Yvonne Underhill-Sem have interjected feminist questions into the literature on development, challenging us to see beyond the accepted wisdom of the neoliberalizing discourses shaping trade and aid flows in the region (Slatter 2006; Underhill-Sem 2003). Such feminist interventions serve as important models for deconstructing commonsense notions of how things are and how they should be, while keeping the social and political stakes of such projects clearly in the frame.

Finally, closer still to the project at hand is the small but growing body of relatively recent work on Pacific masculinities. Brendan Hokowhitu's sustained analyses of constructions of Māori (and to a lesser extent other Pacific) masculinity in Aotearoa/New Zealand are a particularly salient reference point and will be returned to at various points in this essay (Hokowhitu 2003a, 2003 b, 2004, 2008). Also especially noteworthy are special issues of two journals—both published in 2008 and derived from colloquia hosted by the Gender Relations Centre at the Australia National University's Research School of Pacific and Asian Studies. In her introduction to a special issue of The Contemporary Pacific on Oceanic masculinities, Margaret Jolly noted, "Although much has been written about men in Oceania, there has been far less theoretical interrogation of diverse and changing masculinities" (2008, 3; italics in original). Doing its part to address this notable paucity of published research, The Australian Journal of Anthropology (TAJA) shortly thereafter published its own special issue on changing Pacific masculinities, edited by John P Taylor (2008). Despite their both originating from gatherings at the Australian National Uni- 
versity, the two collections differ in geographic and disciplinary predilections: essays in The Contemporary Pacific (TCP) focused primarily on the eastern Polynesian contexts of Hawai'i, Aotearoa, and the Cook Islands, with one central Pacific (Fiji) and one Micronesian (Kwajalein) exception; the TAJA special issue, by contrast, foregrounded its intention to focus, with one exception (Cook Islands), on Melanesian locations, especially Papua New Guinea-a focus Taylor openly acknowledges as tied to Australia's geopolitical prerogatives. While anthropologically informed, the $T C P$ essays collectively befit the interdisciplinary trajectory of the journal, with ample lashings of poststructuralist and critical cultural studies scholarship evident; the papers chosen for the TAJA issue were more specifically intended to pragmatically link discourses of anthropology and development in order to "foster a discussion of the regionalism of applied social science in Australia" ( $\mathrm{J}$ Taylor 2008, I 25).

Both special issues represent important contributions to the developing literature. Both primarily focus on discourses about Pacific men who are in "their" Islands but also raise critiques of the production and circulation of such discourses by metropolitan countries (including, in the case of Māori in Aotearoa or Kānaka Maoli in Hawai'i, when their Islands have become part of metropolitan countries). Absent from both collections, however, is any extended discussion of metropolitan representations of the Pacific men who have migrated to the metropole, or are the descendants of migrants. Also absent from both special issues-save for a paragraph-long anecdote in Jolly's introduction-is any discussion of Samoan masculinities or the discursive terrains that inform them.

Furthering our understanding of Pacific articulations of masculinity in sites specifically_and contestedly_constituted as "American," Vicente Diaz (2002) and Ty Kāwika Tengan (2008) have unpacked the confluence of American-hegemonic, indigenous, and "local" masculinities in Guam and Hawai' $i$, respectively. Importantly, Diaz and Tengan have engaged, with critical sensitivity, the investments of Pacific men themselves in their articulations of masculinity. For those associated with Guam's Tamuning Eagle football team, this might mean "knowing what it means to be a winner at the colonizer's own game," (Diaz 2002, I94), while for the men of Hawai'i's Hale Mua, it is precisely about the development and deployment-the "re-membering" — of an indigenous masculinity understood as oppositional to US hegemony (Tengan 2008). Diaz and Tengan have both historicized such articulations within matrices of power relations, contextualizing men's desires for consequentiality and a sense of efficacy in 
colonial contexts. As we shall see, elements of such contexts-especially the naturalization of Pacific men as football players and warriors-are relevant to a discussion of representations of Samoans in the United States. There are, however, particularities to Samoan mythogenesis-a consistency and coherence to popular narratives about Samoans in the United States-that require unpacking.

Returning to Clyde Taylor's neologism, mythogenic: where Taylor's work differs from the critical genealogy of mythography I've thus outlined is in his intriguing adoption of the suffix -genic. With its etymological roots in the Greek - $\gamma \varepsilon v \eta$ s, by way of the French -gène, the suffix has a slippery triple connotation, meaning both "producing, generating" and "produced by, generated by," as well as "well suited for reproduction or dissemination in a particular medium." Taylor clearly intends at least the first two senses of the suffix: not only are black men the object of others' "layered fictions," but they also, "as if in self-defense," are "prolific generators of self-descriptive legends" (I994, I69). Often, as with the sensationalized gangsta/pimp/thug narratives emerging from the fantasy world of US commercial rap music, lines are blurred between societal myths produced about black men and those produced by them (H Gray I995; Mercer and Julien I988).

The third meaning of -genic is trickier, however, and more worrying: it implies that there are inherent qualities of black men, and by extension Samoans and any other "mythogenic" population, that make them naturally more suited to the production and dissemination of myths about them. The problem with this third definition is that it suggests the very normalization of meaning that the critical scholars named above seek to expose in their work: it is impossible to write about what might make Samoans inherently different from other populations-the qualities they might possess that make them "more suitable" for myth creation-without already investing that difference with meaning.

It is with this in mind that this essay engages the first two senses of mythogenic, while the third connation is purposefully avoided. Rather than attempt to pin down a real referent for social constructions of a "giant" Samoan body by surveying the vast body of scientific literature on Samoan body mass indices (itself indicative of a particular, peculiar fascination), ${ }^{2}$ I attempt instead to illuminate how narratives of absolute difference are being constructed and circulated and the power relationships that are consequently enabled and foreclosed. Whether or not Samoans are physically larger, on average, than other populations is not the issue; 
what matter are the societal effects, the subtly insidious differentials of powers, maintained by people thinking that they are, and then investing that difference with meaning.

\section{Fleeting Substantiality: The Samoan Giant IN US POPUlar Discourse}

There exists a substantial body of work across the fields of postcolonial studies, cultural studies, critical race theory, and psychoanalysis that explores and critiques socially produced conceptions of human difference based on physical attributes such as skin color, hair texture, athleticism, or presumed genital size or sexual ability. In popular discourse, a persistent focus on the physicality of Samoan and other Pacific Islander male bodies as objects generating a powerful range of emotions-awe, fear, respect, desire-corresponds in some ways with long-standing fascinations with black male bodies. Not surprisingly, US critical race theory has selectively been taken up by scholars in Pacific contexts. For example, the poststructuralist work of Brendan Hokowhitu, referenced earlier, draws from US literature on the discursive construction of the black male sporting body to critique representations of Māori masculinity in the New Zealand context.

In the US context, however, there seem to be crucial differences in histories of black and Samoan representation that caution against recognizing similarity at the expense of particularity. Sexual mythology, for example, does not play so central a role in Samoan male mythogenesis as it does in black male mythogenesis, where fixation on the phallus is paramount (Baldwin 1964; H Gray 1995; C Taylor 1994). When surveying popular representations of Samoan men in the United States, it becomes apparent that it is another physical marker, body mass, that underpins many narratives about Samoan ethnic distinctiveness and informs a narrow range of archetypes of Samoan masculinity: the Football Player, the Wrestler, the Bouncer or Bodyguard, and the Gangsta. Thus, the Samoan male body's ability to generate fascination, awe, and a sense of threat has to do with the size of the body parts that are seen, rather than the presumed size of a body part that isn't. Given the absolute centrality of physical size to the stories told about Samoans in the United States, Ellison's metaphor of Gulliver as a racialized giant seems doubly appropriate. How has a giant Samoan body been pinned into place, immobilized, and fixed in American imaginations-the stage and scene for new American stories? 


\section{SPORTS}

A brief survey of the US mediascape (Appadurai I996)—particularly print and television news, popular literature, and film-is useful for illuminating the centrality of body mass to public perceptions of Samoan people in the United States. References to overall size and physicality are particularly rife in the world of sports, where Samoan men are disproportionately represented on university and professional football teams. In addition to physical size, Samoans' "natural" suitability for aggressive contact sports is also often given the gloss of a cultural explanation. Take for example this excerpt from a story on football in American Sāmoa, published on the website of major cable sports network ESPN: "Samoans once were known as fierce warriors who practiced cannibalism. Now they take their aggressions out on the football field, and they do so with uncanny power and skill due to a potent brew of genetics and culture. Their bodies are naturally big-boned; traditional dances make them nimble; and a disciplined upbringing emphasizes the group over the individual, wiring them for team sports" (Miller 2002). Descriptions such as these are typically delivered with a sense of valorizing praise for a people who are, as one of the players quoted in this article puts it, "born to play" football. These comments are also, as in this example, oft-maintained by Samoan men themselves, who rightly feel pride and accomplishment in their sporting aptitude or that of their peers and relish the praise it brings. These are the seemingly benign—-some would even say "positive" - representations of a Samoan physicality that has been disciplined and channeled into productive service: the formerly savage giant's warrior strength harnessed for the good of the team and the benefit of society. ${ }^{3}$

In professional wrestling, where they are also disproportionately represented, Samoan performers have often played on stereotypes of Pacific Islanders, creating larger-than-life personas of both noble chiefs and crazed wildmen. For many Americans, the first salient visual representations of Samoans they would have encountered in popular culture were wrestlers like "High Chief" Peter Maivia in the I970s, the Wild Samoans (Afa and Sika Anoa'i) in the I980s, and the burgeoning younger generation who have since followed them into the ring. As "sports entertainment," professional wrestling relies on well-worn tropes of both valorous and dangerously destructive masculinity, presented according to scripted story lines where over-the-top characters (often ethnic, regional, or subcultural caricatures) do battle both inside and outside the ring (Sammond 2005). 
Academic analyses consistently indicate that professional wrestling promotes "themes of violence, strength through muscularity, toughness, emotional restraint, and athleticism"-all traits associated with "hegemonic masculinity" in the United States (Soulliere 2006, paraphrasing Cherry 2002). Today, the soap-operatic "sport" that Barthes once famously called a "spectacle of excess" (I972, I5) has become more spectacular, more excessive. While representations of Samoans have been no more extreme in this surreal world than those of other racial or ethnic groups, these representations are notable because, unlike whites, blacks, or Latinos, audiences may have few points of reference for Samoans outside of the ring. Thus, for the sport's 40 to 50 million weekly viewers, the body-slamming, pile-driving, fearsome giants of World Wrestling Entertainment may represent the extent of what is known about Samoan populations as a whole.

\section{LITERATURE}

An emerging mythography about Samoans in the United States is particularly apparent in popular literature and film. A relatively early example is celebrated literary figure and "New Journalism" proponent Tom Wolfe's "Mau-Mauing the Flak Catchers," a deeply cynical essay on ethnic radicalism and public assistance bureaucracies in the late-1960s Bay Area (1999). The essay initially appeared as part of a book in I970 but circulated more widely via its reprinting in Cosmopolitan in April I97I-a period in which the serial publication was transitioning from its former literary focus to its current incarnation as a populist women's magazine. The text offers extended passages describing Samoans. These are particularly illuminating because they feature alongside descriptions of Chicanos, Filipinos, Chinese, and, especially, blacks. Wolfe detailed the differing capacities of these various ethnic groups to intimidate and provoke fear in the white male functionaries of the public service bureaucracy. Black men, for all the reasons explored in the volumes of literature on race in America, are infinitely intimidating, regardless of whether they appear as bereted militants or fedora'd pimps. Chicanos and Asians, by contrast, are frightening to whites as an abstract idea (encroaching hordes), but not so much on an individual level in person-unless, as Wolfe recounted, they adopt the styles and idioms of blacks. As for Samoans, Wolfe called them "the original unknown terrors." "In fact," he added, "they were unknown terrors and a half," capable of inspiring fear even without having to play black. "Why so few people in San Francisco know about the Samoans is a 
mystery," Wolfe effused. "All you have to do is see a couple of those Polynesian studs walking through the Mission, minding their own business, and you won't forget it soon" (I999, 9I).

While Wolfe used the heavily loaded term "stud," nothing else in his literary depictions of Samoan men attributes to them the same expectation of hypersexuality linked to the black men he described. The preeminent focus is body mass, as is patently clear in the remainder of this passage: "Have you ever by chance seen professional football players in person, like on the street? The thing you notice is not just that they're big but that they are so big, it's weird. . . . You get the feeling that football players come from a whole other species of human being, they're so big. Well, that gives you some idea of the Samoans, because they're bigger. The average Samoan makes Bubba Smith of the Colts look like a shrimp. They start out at about 300 pounds and from there they just get wider. They are big huge giants" (Wolfe 1999, 9I-92; italics in original).

Several pages on from this initial description, Wolfe recounted a confrontation between a bureaucrat and a multiethnic group of community men. The bureaucrat sizes up each of the different ethnic groups in turn: "The blacks and the Chicanos he has no doubt seen before, or people just like them, but then he takes in the Filipinos ... they look bad. Then the man takes in the Samoans, and they look worse. There's about ten of them but they fill up half the room." Wolfe described these Samoan men in vivid physical detail, from the "long curly strands" of their hair down to their "huge feet" and the straps on their sandals that "look like they were made from the reins of the Budweiser draft horses." In addition to the "sheer physical size of the brutes," what also really intimidates the bureaucrat is the intricately carved "tiki canes"- "like Polynesian scepters" and "the size of sawed-off pool cues"-that the Samoans carry (Wolfe I999, 97; italics in original).

Presumably a description of the Samoan orator's staff, or to'oto'o, Wolfe's focus on this additional detail is noteworthy. In the narration of the bureaucrat's anxiety, the staffs contribute an additional element of exotica, adding a further fear of the unknown (what are they for? what will the men do with them?) to the man's existing trepidation about the Samoans' physical size. ${ }^{4}$ As with the stories endlessly cycling in the world of sport, it is both the dominant narrative of size and this additional narrative of exoticness-this hint of culture that is somehow outside or anterior to Western modernity-that distinguish Samoan mythogenicity, in Wolfe's writing, from that of blacks and other ethnicities. 
FILM

While Wolfe's work is widely read, literary representations do not circulate nearly as broadly as popular film. The hugely successful Pulp Fictionnominated for seven Academy Awards and Time Magazine's "movie of the year" for 1994-also makes passing reference to Samoan size. In an early scene introducing the characters Vincent and Jules (the "low-rent hit men" played by John Travolta and Samuel L Jackson), the two engage in a running banter regarding their badman employer, Marsellus Wallace, en route to paying a lethal visit to some of Wallace's debtors. We learn that Wallace is rumored to have had another man, Antwan Rockamora, thrown from a balcony simply for having massaged the feet of Wallace's new bride. "You remember Antwan Rockamora? Half-black, half-Samoan, usta call him 'Tony Rocky Horror'?” Jules asks Vincent. "Yeah, maybe. Fat, right?" comes the reply, to which Jules responds, "I wouldn't go so far as to call the brother fat. I mean, he's got a weight problem. What's the nigger gonna do, he's Samoan" (Tarantino I994, I 8).

This scene is presumably in the movie to establish Wallace as a man to be feared, to build audience expectation about what might transpire when Vincent has to chaperone Wallace's wife in a later scene, and to further set the tone of absurdity writer/director Quentin Tarantino characteristically crafts in his interplay of extreme violence, mundanity, and inanity. This passing reference to another (unseen) character's half-Samoan ethnicity is no more necessary to the film than the various other Pacific Islands references dotted throughout the script: the person Jules will shortly kill happens to be eating a "Big Kahuna burger" from "that Hawaiian burger joint"; after conning Wallace out of some money, the aging prizefighter Butch (Bruce Willis) and his girlfriend suggest retiring to Bora Bora or Tahiti. Such references are really more about texture rather than substance, potentially unremarkable verbal pit stops in what one critic calls Tarantino's "guided tour of an infernal theme park decorated with cultural detritus" (O'Brien I994, 90). The movie's aesthetic, as the title Pulp Fiction implies, is about a debased, lurid tackiness, and in this context these invocations of Pacific places and people-much like Hunter S Thompson's "Samoan" Dr Gonzo and ever-present aloha shirts ${ }^{5}$ - have all the cultural import of a Las Vegas tiki bar.

While fleeting and seemingly inconsequential, the reference to "Tony Rocky Horror" is nevertheless significant in its affirmation of a commonsense perception of Samoans. It is as if the fact of Samoan ancestry equates 
to a sort of biological fait accompli where bigness is the only imaginable result; nothing more need be said. The implication is that morphological deviance is hardwired in a Samoan's genetic makeup.

A further example, straddling the worlds of both popular literature and film, is novelist Elmore Leonard's mixed Samoan-African American character Elliot in Be Cool (I999), played by Samoan-African American professional wrestler-turned-actor Dwayne "The Rock" Johnson in an otherwise totally forgettable screen adaptation. Although scripted as gay-a fact that might alter the reader's assessment of Elliot's masculinity-the character is still marked in the text by his size and propensity for violence. Leonard's novel says that, after a stint in a correctional facility, Elliot "was a roadie for different bands, a bouncer, then a roadie for the Boo-Yaa T.r.i.b.e., the famous Samoan rappers. ... When Raji asked him what he could do Elliot said, 'I can throw a man through a hotel window ten floors up. I can break a man's arm, I can cut him good. What you want done?"” (Leonard I999, I75).

This passing invocation of real public figures, the Boo-Yaa T.R.I.B.E., in an otherwise fictional narrative notably links the character of Elliot to the preexisting public mythos surrounding the well-known Samoan rap group. Another film, The Italian Job-the 2003 remake of the 1969 Michael Caine thriller-actually casts two members of the Boo-Yaa T.R.I.B.E. The character Skinny Pete-the imposing figure on whose underworld connections the main characters rely when planning their heist-is played by the youngest member of the group (currently composed of five brothers and a cousin), and is credited only by his nom de guerre, Gawtti. Though uncredited, Gawtti's real-life brother and original Boo-Yaa member Donald "Kobra" Devoux also appears briefly in the movie as Skinny Pete's bodyguard.

While the role of Skinny Pete is a small one in terms of actual screen time and billing, this insubstantiality in The Italian Job's narrative is curiously balanced by the substantiality of the ironically named character himself, both as he is physically embodied by the towering, 400-plus-pound Gawtti and as he is deferentially treated by the main characters. Given director F Gary Gray's decision to cast white rapper-turned-actor Mark Wahlberg and black rapper-and-actor Mos Def as Charlie and Left Ear, two of the lead roles, a dense interplay of meaning is created when the pair meet Samoan rapper-and-actor Gawtti's Skinny Pete. "Don't stare," warns Charlie just prior to the meeting. "He doesn't like when people stare at him." Left Ear, who has never seen Skinny Pete, is baffled-"Stare 
at what?" Despite the warning, Left Ear subsequently gapes in slack-jawed awe. "What's wrong?" Pete twice asks, with increasingly forceful menace, as Left Ear stares, stutters, and then studiously tries not to stare. The situation is barely navigated to a successful conclusion by the quick-thinking Charlie, who pacifies the potentially violent giant by redirecting the conversation back to their black-market business transaction.

Reading The Italian Job for the additional layers it may add to Samoan male mythography, I am struck first by that fact that, of all the members of the Boo-Yaa T.R.I.B.E., the tallest and heaviest was cast as Skinny Pete. Once again, the viewing audience sees only brief images of a physically massive man whose size becomes foregrounded as a potent source of tension and suggested threat. Second, I ponder a troubling conundrum, in which it is precisely what makes Skinny Pete consequential in the temporally finite moment of the scene described above-his substantial size and the fear it inspires-that renders the actor who portrays him forever subsidiary to the main cast. Physical size is what makes the giant meaningful, but it also defines the limits of his meaning; he is allowed no other role.

A final film, Gridiron Gang, congeals virtually all of these emerging tropes of Samoan masculinity into one feel-good cinematic stew. A dramatization of an award-winning documentary, the movie chronicles the tumultuous debut season of an actual high school football team from a California juvenile correctional facility. Starring Dwayne Johnson as inspirational corrections officer and coach Sean Porter, the movie follows a group of young juvenile detainees who, as the Porter character relates, have trouble "responding to authority, being a member of a team, and accepting criticism." One of the youths, Junior Palaita, is Samoan both in real life and as portrayed in the movie by Samoan actor Setu Taase. Lead actor Johnson is of course also part Samoan, but he does not portray a Samoan in the movie. Possibly by virtue of his mixed-race ambiguity, as well as his preexisting professional wrestling popularity as "the people's champion," Johnson is one of the few non-white actors in Hollywood who has managed to transcend ethnic-specific typecasting. In real life Coach Porter is white. In the movie, the character's racial identity is never directly referenced, but Johnson's obviously brown skin is implicitly explained when we see him visiting his black mother in the hospital.

The appearance of two Samoan actors in the movie-one cast as a Samoan, one not-makes for an intriguing contrast. While Dwayne Johnson is about the same size as the real Sean Porter (if substantially leaner, as befits a Hollywood action star), the viewer can't help noticing that the 
real life Junior Palaita-seen in excerpts from the original documentary that screen during the end credit sequence-appears considerably smaller than the actor cast to play him. Whether or not this was a calculated casting decision (and one does wonder whether a small Samoan man will ever be cast as a "Samoan man" in Hollywood), ${ }^{6}$ the end result is that the only character explicitly marked as Samoan in the movie is also the tallest and possibly the heaviest. There is one black character who is notably obese, but given the wide range of black male phenotypes presented onscreen, he in no way comes to represent black bodies in the way that the Junior character represents Samoans. In the film, Junior's substantial size heightens the sense of narrative tension, and ultimate feel-good resolution, as he progresses from destructive, rampaging giant-so potentially disruptive that he is not, at first, allowed on the team-to the disciplined, productive, sacrificial giant whose big, injured body enables a crucial play at a critical moment.

\section{SAvage Discourse}

In these examples, the sense of threat attributed to Samoan characters does not contain the sexual dimensions typically associated with representations of black men. James Baldwin once famously asserted that "to be an American Negro male is also to be a kind of walking phallic symbol: which means that one pays, in one's own personality, for the sexual insecurity of others" (1964, I78). By contrast, in the films discussed above, other characters' awe and trepidation owe to a fear of someone bigger, stronger, and capable of doing them physical harm. Pulp Fiction's Antwan Rockamora-whose intimate contact with another man's wife causes concern-is the one possible exception, but recall that that character is also half-black and therefore doubly mythogenic.

There are additional factors contributing to Samoan mythogenesisalso indicated in many of these examples-that distinguish it, as a process, from the generation of myths about African Americans. Although Samoans may inherit some of the baggage of other racialized populations in the United States, particularly blacks and Mexicans, Samoans also carry their own heavy representational baggage from the Islands. Returning to the Bay Area anecdote with which I opened, recall the intensely curious contrast between students' imaginings of Pacific Islands and Pacific Islanders. Such a starkly interesting juxtaposition of utopian Island locales and dystopian Islander locals in urban American neighborhoods is common 
enough to have received comment elsewhere. Summing up these intriguingly dichotomous representations of Samoans in the northwestern United States, Barbara Burns McGrath noted, "The impression of many is based on popular media reports, which produce a picture of aggressive, physically large males who make great football players but fearsome gang members. This exotic image overshadows the rest of the population, completely dismissing women, elders, and children. Being misrepresented in westerncreated images is nothing new for Polynesians. It is interesting, however, that the earlier representations predominantly featured Polynesian women as sensual and free-spirited, but once they leave the islands the image shifts to menacing young men" (2002, 324-325). While not named outright, the enormous influence of Margaret Mead's ethnographic work earlier in the twentieth century is implicit in McGrath's comment. And here is the additional baggage Samoans carry: newly condensing representations of masculine aggression and physical menace are curiously provided an additional weight because they are routinely counterposed to the earlier depictions of femininity parlayed by Mead, which are in turn informed by a longer history of gendered representations of primarily eastern Polynesian women (Tcherkézoff 2004).

The feminized, Island-rooted vision of easygoing sensuality associated with Mead's Coming of Age in Samoa (I928) provides such an acute contrast to visions of hyperaggressive urban American gangstas that scholars whose work is not particularly associated with the Pacific nevertheless employ its narrative effect. In the introduction to their 1996 edited collection Displacement, Diaspora, and Geographies of Identity, anthropologists Smadar Lavie and Ted Swedenburg invoked the Mead/menace dichotomy for no smaller purpose than illustrating the conceptual crisis of anthropology. The book's introduction delineates the breakdown of a previous anthropological paradigm that divided the world into a modern Here (the West) and a presumably timeless Out There (Non-West). "The notion of culture ... that immutably ties a culture to a fixed terrain, has become increasingly problematic," wrote Lavie and Swedenburg. "The 'savage' is no longer out 'there' but has invaded the 'home' Here and has fissured it in the process." The chapter's first concrete example of these processes is immediately thereafter provided in a parenthetical rumination: "(What would Margaret Mead have made of Samoan gangs in Los Angeles, or of the L.A.-Samoan gangsta rap group the Boo-Yah Tribe [sic], named after the Samoan term 'boo-yah!,' for a shotgun blast in a drive-by shooting?)" (Lavie and Swedenburg I996, 2).7 
Displacement, Diaspora, and Geographies of Identity is an important collection of anthropological essays examining the terrain of what the editors, building on the postcolonial studies work of Homi Bhabha (I990) and Trinh T Minh-ha (I991, I 55-236), called the "third time-space." Lavie and Swedenburg called for ethnographic and theoretical examination of "the guerrilla warfare of the interstices, where minorities rupture categories of race, gender, sexuality, class, nation, and empire in the center as well as on the margins" (I996, I3). That Samoans, and specifically the Samoan American rap group the Boo-Yaa T.R.I.B.E., appear in such a way in the introduction of the volume is possibly incidental, but perhaps it bespeaks a certain centrality of Samoans to anthropological imaginations in the United States. Thanks to the work of the young Margaret Mead, Sāmoa looms far larger in an ethnographic imaginary than either its modest geography or demography would suggest. What better ethnic group, then, to stand in for Everynative, the onetime anthropological subject come to trouble an easy distinction between Here and There? And what better image to convey that sense of rupture than the juxtaposition of the playfully sensuous adolescent girls, inferred by the reference to Margaret Mead, and the gun-wielding gangsta rappers of the Boo-Yaa T.R.I.B.E.?

While Lavie's and Swedenburg's loaded invocation of the Boo-Yaa T.R.I.B.E. certainly seems to disrupt anthropological myths about Samoans formed earlier in the twentieth century, it is, in fact, in keeping with newer American myths coalescing now. But are these myths really as new as they seem? Popular representations of Samoan men in the United States draw from a contextually specific constellation of factors in urban American cities, but there are also familiar echoes of an older representational economy at work that dates much farther back than Mead. This is the other way that Samoan mythogenesis significantly departs from black or African American mythogenesis: it draws also on a rather different, centuries-long trajectory of Western imagining of Pacific Islanders as "savages." This is not to say that the term "savage" has not also been heaped on African Americans-of course it has, but not in precisely the same way. Recall, for example, Tom Wolfe's simultaneously derisive and fearful invocation of Samoan "tiki canes": while Samoans sometimes inherit racial US mythography originally crafted for peoples of African ancestry, it is their presumed connection to an indigenous culture that is understood as anterior or outside the West that casts them as "primitive" in a manner different from American blacks, whose culture-as Paul Gilroy (I993) and others have noted-is precisely a product of modernity. This is the 
important distinction Teresia Teaiwa illustrated when she discussed how "the Native" - often the subject of Pacific Studies-has historically been constituted differently than the black subjects of influential cultural studies scholars like Gilroy and Stuart Hall. While Gilroy's work intervenes in the discourse of racism that "locates a Black Briton-especially as a worker or labourer-in a racial or functional hierarchy within modern society," Pacific studies is more often forced to wrestle with a related exoticism that, by contrast, "figures an African tribal chief-the Native-as somehow outside of or external to the present, a bizarre historical survival, a discrepancy in modernity's cultural accounting system" (Teaiwa 2005 , I6). In the United States, Samoans remain squarely within the purview of anthropology, the discipline created, however problematically, to know the Native, the Other, "out there." By contrast, blacks in the United States—as opposed to the Nuer, or the !Kung in Africa-remain squarely within the purview of sociology. They are the Other within-not the Other newly arrived here, but the Other that America in fact created.

Vacillating images of savagery have marked popular representations of Pacific Islands and Pacific Islanders since the explorations and conquests of the French, British, and Americans in the eighteenth and nineteenth centuries. Pacific historian Kerry Howe noted the discursive mobility of "the savage" in Pacific historiography, where Island peoples are variously understood as noble and in need of protection, or ignoble and in need of redemption, containment, and control (Howe r977). This slippery mobility of "savage discourse" is a point persuasively echoed by Brendan Hokowhitu in his work on constructions of Māori and Pacific masculinity: "Representing the racialised body as unchanging and immutable is a tactical discourse that constructs the Other as forever tied to their primitive biological roots, yet sardonically, representations of the Other, because they are tactics of power, necessitate fluidity to enable representations to vary with the changing context. Like the chameleon, the images of the coloured body mutate to reflect the changing landscape" (Hokowhitu 2003 b, 26). Whether classed as "good" (entertaining, useful) or "bad" (menacing, problem-causing) savages, the core of the representational lexicon remains rooted in a Cartesian dualism clearly equating Pacific peoples with primitive physicality rather than modern rationality.

When viewed from the critical lenses of Howe and Hokowhitu, the manner in which Lavie and Swedenburg contrast Mead's pleasantly benign native subjects with the performative violence of the Boo-Yaa T.R.I.B.E. seems to echo a much longer flip-flopping pattern of depicting Pacific 
peoples as purveyors of both physical pleasure and physical threat. So it is not so much a rupture, or contradiction, as it is two sides of the same coin. What has shifted is that the older discourses of savagery dating to the period of European exploration, missionization, and settlement of the Pacific-and even the sharply contrasting "diptych" of Samoan culture presented in the more recent Mead-Freeman debates (Clifford I986) wrestled over the representation of Islanders in the Islands, whereas this new articulation contrasts the noble savage in the Islands with the ignoble savage coming of age in urban America.

\section{Articulation, Ambivalence, and the Stakes of Samoan Mythogenesis}

Lavie and Swedenburg's brief parenthetical reference to the Boo-Yaa T.R.I.B.E., like Pulp Fiction's throwaway comment about the inevitability of Samoan body size or the fleeting appearances of Skinny Pete in The Italian Job, is significant precisely for its seeming inconsequentiality. It matters that readers and viewers get these fleeting references, and only these; Samoan bodies-invariably male, invariably big-form an exotic tropical punch line or exclamation point in a text that's really about something else. I am sympathetic to Lavie and Swedenburg's larger project of attempting to theorize a third time-space, in the border zone between an outmoded formulation of "identity-as-essence" and a newer but potentially problematic theory of "identity-as-conjuncture." If the dangers of the former are obvious, the latter, they caution, risks overemphasizing the playful malleability of identity while downplaying the politicized contexts that structure this "play."

The questions raised by Lavie and Swedenburg are central to my own understanding of the benefits, and limits, of articulation theory, as developed by Stuart Hall (Grossberg I996; Hall 1986a, I986b) and James Clifford (200I). Articulation theory is a type of identity-as-conjuncture theory, but one that, ideally, pays close attention to the politicized terrain on which some junctures are possible and others are not. Clifford asserted, in language quite commensurable with Lavie and Swedenburg's: "We need to discover a jagged path between the seductions of a premature, postmodern pluralism and the dangerous comforts offered by exclusivist self-other definitions" (200I, 470). Hall's metaphor of the articulated lorry (Clifford 200I), coupling and uncoupling parts as necessary, is a handy model for envisioning processes of identity formation that seem 
to resemble what Lavie and Swedenburg called the "'differential' mode of resistance that situationally opts for the most effective strategy of the moment" (I996, I7). Yet (and I think this is Lavie and Swedenburg's point, too), societal structures of dominance set limits to all this hooking and unhooking; in the US context, pervasive representations of Samoan male physicality structure expectations of Samoan men both within and without Samoan communities, curtailing alternate models of identity that could just as plausibly be justified.

What are the stakes, the real world effects, of Samoan mythogenesis? One vivid example is the way that expectations about Samoans-what they are like, what they are capable of-structure Samoan experiences with public-sector institutions such as education and law enforcement. Research in Hawai'i suggests that popular perceptions of Samoan and other Polynesian high school students as "big, tough, and violent" results in young men being tracked into sports, with athletic achievement being their only expected pathway to success (Chesney-Lind, Koo, and Mayeda I998). Samoan communities, both in the continental United States and Hawai'i, have also long maintained that they are victims of police prejudice. Disproportionately high rates of Pacific Islander arrest and detention (Stewart 2005) and police assaults on unarmed or minimally armed Samoan adults in California and Hawai'i indicate that the stakes of public perception are acute. The widely publicized police brutality case won by the Cerritos, California-based family of Samoan former professional wrestler Emily Dole, as well as the fatal police shootings of Pouvi and Itali Tualaulelei in Compton, California, in I99I; Rodney Laulusa in Honolulu, Hawai'i, in I998; and most recently Roketi Su'e in Long Beach, California, in 2008-and officers' subsequent statements in these cases indicating that size was a factor in their assessments of risk and threat-all suggest that popular representations of big, violent Samoans may have tragic consequences.

Just as worrying are the ways popular mythologies contribute to shaping Samoan perceptions of themselves in the United States. Many Samoan men-and women-evidence deep ambivalence about popular myths about Samoans, decrying harmful stereotypes in one breath and reinscribing them in the next. In a newspaper article that appeared after the Tualaulelei incident, the onetime head of the Los Angeles area Samoan Council of Chiefs, Pele Faletogo, was quoted as saying, "Everybody thinks we are big-body people and can beat everybody up. But under the Samoan, under his 6 -foot 5 -inch, 280-pound body, is the heart of a lamb. He would give 
away his last dime to whoever needs it. . . But don't (anger) him either" (Archibold I993, 3, italics added). Similarly, in a Honolulu Weekly article following the shooting of Rodney Laulusa, Chez Ma'ea, a longtime resident of Hawai'i originally from American Sāmoa, began critically, "Police brutality is a big problem in Hawai' $i$-there's a fear and stereotypes of Samoans." But at least as journalist Ed Rampell quoted him, Ma'ea quickly paired this narrative depiction of Samoans as victims with direct reference to Samoans as potential sources of threat: "With incidents happening over and over, people get fed up [fiu] and will stand up ... That's how terrorism and underground movements are born... There are lots of violent Samoan gangs in L.A. that could retaliate in Hawai'i" (Rampell I998, 7; ellipses in original).

Of course, we can, and should, question whether the authors of news articles unwittingly reproduce popular narratives of Samoan aggression by asking leading questions, selectively editing transcripts, or both. We might wonder, for instance, what exact words Faletogo used, since the journalist placed parentheses around "anger." It's also worth noting that Rampell preceded his quotation of Ma'ea with references to him as a "tall, muscular, tattooed man" (I998, 7), thereby reinforcing familiar narrative elements of size, exoticness, and associated threat. However, my own experiences speaking with hundreds of young, US-based Samoan men and women in the course of formal research and in informal contexts indicate that Faletogo's and Ma'ea's flip-flopping invocations of Samoans as both victims and potential aggressors reflect a deep-seated ambivalence that is exceedingly common. Such narratives are charged with complex contradictions-people are shamed and angered by the negativity associated with the violent stereotype but proud of the respect and bragging rights, the consequentiality, it engenders. Consider these reflections from a twenty-seven-year-old Samoan male raised in a Honolulu housing project: "Where I was raised ... Samoans were already stereotyped as troublemakers. But that's what the kids in the neighborhood wanted to live up to. They wanted to be that troublemaker and they wanted that respect... regardless if you like 'em or not, they gonna earn your respect through fear and intimidation ... they don't stop to think 'Oh, maybe I can be smarter than the next man' ... Why? That's a longer process. Everybody's looking for the shortcut" (quoted in Henderson I999, 88). Affective currencies of status, deference, and respect are compelling for men whose options for gaining access to the abstract power of boardrooms and legislative floors are curtailed by class and a lack of educational opportuni- 
ties. This is particularly the case for young men growing up as part of what some have called "the hip hop generation," as anti-sexism activist Jackson Katz explained in a documentary on hip hop and masculinity in the United States (Hurt 2006): "If you're a young man growing up in this culture, and the culture is telling you that being a man means being powerful, being dominant, being in control, having the respect of your peers, but you don't have a lot of real power, well one thing you do have is access to your body and your ability to present yourself, physically, as somebody who is worthy of respect. ... Men who have more power, men who have financial power and workplace authority and forms of abstract power like that don't have to be as physically powerful because they can exert their power in other ways." In a terrain where options and opportunities are constrained, Samoan men—knowingly or unknowingly—parlay myths about the Samoan giant into a form of social capital, reaping what some researchers have called "the ideological benefits of being considered 'tough,' particularly in the context of at-risk locales that valorize machoness" (Chesney-Lind, Koo, and Mayeda I998, 23).

In a related vein, economic necessity must surely rank as an important contributing factor to "giant ambivalence." There may appear to be tangible economic benefits, in the form of legitimate security work or through informal or extralegal avenues, for those considered physically intimidating. Many Samoan men are well aware, even critical, of societal scripts, but nevertheless play them out of a sense of economic necessity. For example, when asked in an interview whether the wrestling successes of his caricature-performing family were "worth exoticizing one's people," Samu "Headshrinker" Anoa'i voiced a resigned economic pragmatism: "Everybody has their own gimmick; people aren't gonna pay money to see somebody they can go to 7-I I and look at" (quoted in Posas 2008, II 5). Walter "High Chief XL" Saole-a hip hop artist and widely recognized figure in Honolulu's hospitality and entertainment industry before his untimely passing in 2010-once speculated to me on the ubiquitous presence of Samoan security personnel in Honolulu nightclubs: "The thing is with Samoans nowadays, it's like the way blacks were back then. Like the whites used to see blacks as good security-'Oh, these guys are big, let them handle it,' y'know? And now the blacks are seeing Samoans like that-'Oh these guys are big, yeah uso [brother], come!' We're bigger than them, physical-wise, and a lot of Samoans will handle the business when it comes to it" (quoted in Henderson I999, 89). The surface simplicity of such a statement belies its narratological complexity, as it weaves between 
the realm of perception (how whites see blacks; how blacks see Samoans) and the realm of the real where claims are made on how things actually are (we're bigger; a lot of Samoans will handle the business). Saole explained his sense that Samoans have become Other to blacks even as blacks have been Other to whites, but he subsequently reinforced the presumptions of Samoan particularity that underpin that Othering. If such slippage hints at ambivalence, our many other conversations in the decade since I recorded this statement confirm it: Saole continued to work for years in the type of security positions that "big Samoan guys" are widely expected to fill in Honolulu, but he privately chafed at the idea that bar patrons might understand him only in such a diminished, monotypic way. As someone privileged to know him as a gifted lyricist, a loyal friend, a mature student steadily slogging toward his degree, a hopeless romantic unabashedly wearing his heart on his sleeve, a beloved son, brother, and uncle helping to raise siblings and their children, a cheeky wisecracker, and a "true hip hop head" who once proclaimed "If you cut me up into part, one part would have to be for hip hop"-I chafed at that thought, too.

Young Samoans growing up in the United States often resent the implications of reductive mythologies while simultaneously finding pleasure and a sense of efficacy in being known as a people "not to be messed with." In the desire for a sense of consequentiality, being physically large seems to compensate for being numerically small; being physically strong seems to compensate for being economically and politically weak; and the substantiality of the Samoan body, when it makes its rare appearance in popular discourse, seems to compensate for the insubstantiality of Samoans or other Pacific Islanders in broader discourses of race in the United States. Thus, Samoans become, to borrow again from Clyde Taylor, "prolific generators of self-descriptive legends" (I994, I69).

This article, in fact, grew initially from my attempts to wrestle with the ways the Samoan American rap group Boo-Yaa T.R.I.B.E. have built their substantial and enduring reputation in the Los Angeles hip hop scene in part by performing the myth of the hyperaggressive, violent Samoan giant. In real life, just as with the character Skinny Pete played by T.R.I.B.E. member Gawtti in The Italian Job, the group's physical size and ability to provoke fear have rendered them consequential in the music industry, even while their intimidating image has defined the limits of their consequence; despite their innovative contributions to hip hop music, popular writing about the group almost invariably focuses on the way they look, and the terror they inspire, rather than the music they make (Cross I993; 
Toop I999). Hip hop culture generates particularly charged spheres where mythologies of race and gender are constantly negotiated, contested, performed, and redeployed; while my work on the Boo-Yaa T.R.I.B.E. and other Samoan artists involved in hip hop continues, this article represents a preliminary mapping and analysis of the discursive terrain that such artists encounter in US popular culture. It is an attempt to not just name the giant in the room, but to show him to be the discursively produced mythological creature he is. The extent to which such mythologies resemble actual Samoan men is only the extent to which we all-including Samoan men-believe these myths to be true and structure our expectations and behavior accordingly.

A conclusion of sorts: initially unbeknownst to me, there was a Samoan student in the room when I delivered one of my guest lectures at the Bay Area juvenile justice facility in 2002. Two-thirds of the way through one of the classes, a slim, brown-skinned young man outed himself as the product of African American and Samoan parents. This was news to both his classmates and his teacher, who all had understood him as "just" black. He explained that he had always wanted to know more about his "Samoan side" but had found it difficult to ask questions of a Samoan grandmother who seemed too distracted by the pressures of daily survival in California to entertain the queries of an inquisitive youngster. In the absence of substantive information from his family, all he had to work with were the discourses circulating in US popular culture and in his local community-discourses that figured Samoans in ways he was unable, physically, to embody. So he had remained quiet about his Samoan ancestry up until that moment when-attentively sitting front and center, in sharp contrast to what his teacher later relayed was his usual back-row posture of exaggerated disinterest-he fired question after question at me about Samoan history and politics, which I tried to answer to the best of my ability by supplementing my personal experiences in Hawai'i, Sāmoa and American Sāmoa, and Aotearoa/New Zealand, with information gleaned from Meleiseā, Kramer, Pratt, Gilson, Wendt, Shore, Macpherson, Holmes, and the like.

In relaying this concluding anecdote, let me be clear that I don't imagine that my one-off guest lecture changed this young man's life-I harbor no self-flattering liberal fantasies of myself as savior-teacher, playing Edward James Olmos to his Lou Diamond Phillips. The pedagogical moment wasn't about me at all; it was about the presentation of information that does not circulate in US popular discourse but is available to those fortu- 
nate enough to study the Pacific in higher education. I am inspired by the memory of that young man, his decision that day to seat himself uncharacteristically in the front row, his fearless posing of question after question, and what I imagine to be his example of clearly, eagerly, working out for himself the broader possibilities of what being Samoan might mean.

This PaPer is Dedicated to the memory of High Chief xL, Walter Jacob Saole (1972-2010), a man of immense talent, intelligence, and grace, who continues to inspire my life and work. This paper is intended for every person who ever thought of Walt only as "The Bouncer."

IN WRITING THIS ARTICLE, I am indebted to three anonymous reviewers for their generous feedback, as well to colleagues who offered constructive comments at its initial airings at the conference "The New Exotic? Postcolonialism and Globalization" at Otago University in June 2009; at a 2009 seminar hosted by the Media Studies Programme at Victoria University of Wellington; and as part of the University of Hawai'i at Mānoa/East-West Center International Cultural Studies Speaker Series in June 20 Iо.

\section{Notes}

I American Heritage Dictionary, 4 th edition (2000); Oxford English Dictionary Online, 3rd edition (2010).

2 See, for example, Dai and others 2007, Galanis and others 1999, and McGarvey and others 2002. For a critique of the controversial hypotheses that a "thrifty gene" predisposes Samoans and other indigenous populations to accumulate and store fat, see Poudrier 2007.

3 For an extended example, see the documentary Polynesian Power (Spear and Pennington 2005).

4 In a sense, Wolfe's read of the "canes" as emblematic of some threateningly Other Polynesian social order is not totally incorrect-insofar as to 'oto'o symbolically represent the authority of the fa'amatai system of chiefly governance in Sāmoa. A to'oto'o appears, along with an orator's flywhisk (fue) and a kava bowl (tānoa), on the seal of the nation of Sāmoa, for example. To varying degrees, these three items represent Samoan culture in diaspora; the same trio of fue, to'oto'o, and tānoa can be found on "identity merchandise" (Linnekin 2004) wherever Samoans have settled. In an urban US context, however, none of the chiefly authority that the to'oto'o represents can be brought to bear on city, state, 
or federal bureaucracies. Wolfe's bureaucrat's fear of these trappings of native authority persists despite the fact that the Samoans hold little actual power other than their ability to cause him fear.

5 In Thompson's drug-fueled psychedelic road trip classic Fear and Loathing in Las Vegas (1972)—which fellow New Journalism compatriot Tom Wolfe described as a "scorching, epochal sensation" on the original hardcover book jacket-the author rendered the Dr Gonzo character as Samoan, purportedly to mask the identity of the real-life Chicano lawyer friend on whom the character was based. References to Dr Gonzo as Samoan were retained in the I998 screen adaptation, in which he was portrayed by Puerto Rican actor Benicio Del Toro.

6 For an intriguing contrast, in 2010, filming commenced on The Orator (O le Tulafale), the first feature-length film to be written and directed by a Samoan. Funded by the New Zealand Film Commission (NZFC), the film is directed by Sāmoa-born, New Zealand-based Tauti Tusi Tamasese and filmed on location in Sāmoa in the Samoan language. The NZFC press release describes the plot of the film in the following way: "The Orator is the story of Saili, a small man with a big heart, who must find the strength to speak up for those that he loves" (NZFC 20I0; italics added).

7 In addition to leaving off the periods that the group typically utilize in their spelling of T.R.I.B.E., this comment misleadingly identifies "boo-yah" as a "Samoan term." The term comes not from the Samoan language but rather from urban US street slang.

\section{References}

Appadurai, Arjun

I996 Modernity at Large: Cultural Dimensions of Globalization. Minneapolis: University of Minnesota Press.

Archibold, Randal C

I993 A Voice for His People: Samoan Chief Tries to Bridge Gap Between Island Tradition and Mainland Reality. Los Angeles Times, 2 May.

Baldwin, James

I98 5 The Black Boy Looks at the White Boy. In Nobody Knows My Name: More Notes of a Native Son, I77-196. London: Michael Joseph.

Barthes, Roland

I972 Mythologies. Selected and translated from the French by Annette Lavers. New York: Hill and Wang. Originally published in French in Paris: Seuil, I957.

Bhabha, Homi

I990 The Third Space: Interview with Homi Bhabha. In Identity: Community, Culture, Difference, edited by Jonathan Rutherford, 207-22I. London: Lawrence \& Wishart. 
Cherry, E

2002 The Toughest sовs on Cable: Gender Roles in Professional Wrestling. Paper presented at the meeting of the Southern Sociological Society, Atlanta, Georgia, April.

Chesney-Lind, Meda, Jennifer J Koo, and David T Mayeda

I998 Issues of Gender and Ethnicity among At-Risk Youth in Hawaii: Identity, Ethnic Relations, Aspirations, and Self-Esteem. A Report of the Hawaii Girls Project, Volume 3 (Report 397). Honolulu: Center for Youth Research.

Clifford, James

I986 On Ethnographic Allegory. In Writing Culture: The Poetics and Politics of Ethnography, edited by James Clifford and George E Marcus, 98-I2 I. Berkeley: University of California Press.

200I Indigenous Articulations. The Contemporary Pacific I3:468-490.

Cross, Brian

I993 It's Not About a Salary... Rap, Race + Resistance in Los Angeles. London: Verso

Dai, F, E D Keighley, G Sun, S R Indugula, S T Roberts, K Åberg, D Smelser, J Tuitele, L Jin, R Deka, D E Weeks, and S T McGarvey

2007 Genome-wide Scan for Adiposity-related Phenotypes in Adults from American Samoa. International Journal of Obesity 3 I:I $832-\mathrm{I} 842$.

Deloria, Philip

I998 Playing Indian. New Haven, ст: Yale University Press.

Diaz, Vicente $M$

2002 "Fight boys, "til the last ...": Islandstyle Football and the Remasculinization of Indigeneity in the Militarized American Pacific Islands. In Pacific Diaspora: Island Peoples in the United States and across the Pacific, edited by Paul Spickard, Joanne L Rondilla, and Debbie Hippolite Wright, I69-I94. Honolulu: University of Hawai'i Press.

Ellison, Ralph

I964 Shadow and Act. New York: New American Library.

Fry, Greg

2000 Framing the Islands: Knowledge and Power in Changing Australian Images of the "South Pacific." In Voyaging through the Contemporary Pacific, edited by David Hanlon and Geoffrey M White, 25-63. Lanham, MD: Rowman \& Littlefield. First published in The Contemporary Pacific 9:305-344 (1997).

Galanis, Daniel J, Stephen T McGarvey, Christine Quested, Brenda Sio, and Salei'a Afele-Fa'amuli

I999 Dietary Intake of Modernizing Samoans: Implications for Risk of Cardiovascular Disease. Journal of the American Dietetic Association 99 (2): I $84-190$. 
Gilroy, Paul

I993 The Black Atlantic: Modernity and Double Consciousness. Cambridge, MA: Harvard University Press.

Gramsci, Antonio

I97 I Selections from the Prison Notebooks. Edited and translated by Quintin Hoare and Geoffrey Smith. New York: International.

I985 Selections from Cultural Writings. Edited by David Forgacs and Geoffrey Nowell-Smith; translated by William Boelhower. London: Lawrence \& Wishart.

Gray, F Gary, director

2003 The Italian Job. Feature film, I I I minutes. Paramount Pictures.

Gray, Herman

I995 Black Masculinity and Visual Culture. Callaloo I 8 (2): 40 I-405.

Grossberg, Lawrence, editor

I996 On Postmodernism and Articulation: An Interview with Stuart Hall. In Stuart Hall: Critical Dialogues in Cultural Studies, edited by David Morley and Kuan-Hsing Chen, I3 I-I 50 . New York: Routledge.

Hall, Stuart

I986a Gramsci's Relevance for the Study of Race and Ethnicity. Journal of Communication Inquiry Io (2): 5-27.

I986b On Postmodernism and Articulation: An Interview with Stuart Hall. Journal of Communication Inquiry Io (2): 45-60.

Hall, Stuart, Chas Critcher, Tony Jefferson, John Clarke, and Brian Robert

I978 Policing the Crisis: Mugging, the State and Law and Order. London: Macmillan.

Henderson, April

I999 Gifted Flows: Netting the Imagery of Hip Hop Across the Samoan Diaspora. MA thesis, Pacific Islands Studies, University of Hawai'i, Mānoa.

2006 Dancing Between Islands: Hip Hop and Samoan Diaspora. In The Vinyl Ain't Final: Hip Hop and the Globalization of Black Popular Culture, edited by Dipannita Basu and Sidney J Lemelle, I80-I99. London: Pluto Press.

2007 Gifted Flows: Engaging Narratives of Hip Hop and Samoan Diaspora. PhD thesis, History of Consciousness, University of California, Santa Cruz.

Hokowhitu, Brendan

2003a Māori Masculinity, Post-structuralism, and the Emerging Self. New Zealand Sociology I 8 (2): I79-20I.

2003b Race Tactics: The Racialised Athletic Body. Junctures: The Journal for Thematic Dialogue I:2 I-34. 
2004 Tackling Māori Masculinity: A Colonial Genealogy of Savagery and Sport. The Contemporary Pacific I 6:259-284.

2008 Understanding the Māori and Pacific Body: Towards a Critical Physical Education Pedagogy. New Zealand Physical Educator 4I (3): 8I-9I.

Howe, Kerry

I997 The Fate of the "Savage" in Pacific Historiography. The New Zealand Journal of History I I (2): I37-I 54 .

Hurt, Byron, director

2006 Hip-Hop: Beyond Beats and Rhymes. Documentary, 56 minutes. Media Education Foundation and God Bless the Child Productions.

Joanou, Phil, director

2006 Gridiron Gang. Feature film, I25 minutes. Sony Pictures.

Jolly, Margaret

I997 From Point Venus to Bali Ha'i: Eroticism and Exoticism in the Pacific. In Sites of Desire, Economies of Pleasure: Sexualities in Asia and the Pacific, edited by Lenore Manderson and Margaret Jolly, 99-I22. Chicago: University of Chicago Press.

2007 Imagining Oceania: Indigenous and Foreign Representations of a Sea of Islands. The Contemporary Pacific I9:508-545.

2008 Moving Masculinities: Memories and Bodies Across Oceania. The Contemporary Pacific 20:I-24.

Lavie, Smadar, and Ted Swedenburg

I996 Introduction: Displacement, Diaspora, and Geographies of Identity. In Displacement, Diaspora, and Geographies of Identity, edited by Smadar Lavie and Ted Swedenburg, I-25. Durham, NC: Duke University Press.

Leonard, Elmore

I999 Be Cool. New York: Harper Collins.

Linnekin, Jocelyn

2004 Tradition Sells: Identity Merchandise in the Island Pacific. In Globalization and Culture Change in the Pacific Islands, edited by Victoria S Lockwood, 324-338. Upper Saddle River, NJ: Pearson Prentice Hall.

Macpherson, Cluny, Bradd Shore, and Robert Franco, editors

1978 New Neighbors: Islanders in Adaptation. Santa Cruz, cA: Center for South Pacific Studies.

McGarvey, S T, W Forrest, D E Weeks, G Sun, D Smelser, J Tufa, S Viali, and R Deka

2002 Human Leptin Locus (LEP) Alleles and BMI in Samoans. International Journal of Obesity 26:783-788.

McGrath, Barbara Burns

2002 Seattle Fa'a Sāmoa. The Contemporary Pacific I4:307-340. 
Mead, Margaret

I928 Coming of Age in Samoa. New York: Morrow Quill.

Mercer, Kobena, and Isaac Julien

I988 Race, Sexual Politics and Black Masculinity: A Dossier. In Male Order: Unwrapping Masculinity, edited by Jonathan Rutherford and Rowena Chapman, 97-I64. London: Lawrence \& Wishart.

Miller, Ted

2002 American Football, Samoan Style. ESPN.com, 28 May. http://sports .espn.go.com/espn/print?id=I387562\&type=story [accessed I April 2009]

Mukerji, Chandra, and Michael Schudson

I99I Introduction: Rethinking Popular Culture. In Rethinking Popular Culture: Contemporary Perspectives in Cultural Studies, edited by Chandra Mukerji and Michael Schudson, I-6I. Berkeley: University of California Press.

NZFC, New Zealand Film Commission

2010 NZFC Announces First Time Feature Film by Samoan New Zealander writer-director. Press release, i I October.

O’Brien, Geoffrey

I994 Quentin Tarantino's Pulp Fantastic. In Castaways of the Image Planet: Movies, Show Business, Public Spectacle, 89-92. Washington, DC: Counterpoint.

Posas, Carlos Nobleza

2008 Born to Wrestle. Frank Book [quarterly] Chapter 35 (Samoa): I I 2I I 7. Also at http://www.frank I 5 I.com/book/chapter_35_samoa/born _to_wrestle

Poudrier, Jennifer

2007 The Geneticization of Aboriginal Diabetes and Obesity: Adding Another Scene to the Story of the Thrifty Gene. The Canadian Review of Sociology and Anthropology 44 (2): 237-26I.

Rampell, Ed

I998 Did This Man Have to Die? Honolulu Weekly 8 (8), 25 February-3 March 3.

Said, Edward

I978 Orientalism. London: Routledge \& Kegan Paul.

Sammond, Nicholas, editor

2005 Steel Chair to the Head: The Pleasure and Pain of Professional Wrestling. Durham, NC: Duke University Press.

Slatter, Claire

2006 Neo-liberalism and the Disciplining of Pacific Island States: The Dual Challenges of a Global Economic Creed and Changed Economic Order. 
In Pacific Futures, edited by Michael Powles, 9I-IIo. Canberra: Research School of Pacific and Asian Studies, The Australian National University.

Soulliere, Danielle M

2006 Wrestling with Masculinity: Messages about Manhood in the wwe. Sex Roles 5 5:I-I I.

Spear, Jeremy, and Robert Pennington, directors

2005 Polynesian Power: Islanders in Pro Football. Documentary, 57 minutes. Produced by ESPN. See also http://www.youtube.com/watch?v $={ }_{5} \mathrm{NZ}_{7 \mathrm{ec}} 8 \mathrm{HjxU}$ [accessed 25 July 2009]

Stewart, Jocelyn

2005 Data Reveal Hard Truths for Islanders. Los Angeles Times, 26 September.

Subramani

2001 The Oceanic Imaginary. The Contemporary Pacific I3:I49-I62.

Tarantino, Quentin

I994 Pulp Fiction [screenplay]. London: Faber \& Faber.

Taylor, Clyde

I994 The Game. In Black Male: Representations of Masculinity in Contemporary American Art, edited by Thelma Golden, I67-I74. New York: Whitney Museum of American Art.

Taylor, John P

2008 Changing Pacific Masculinities: The "Problem" of Men. The Australian Journal of Anthropology I9 (2): I $25-\mathrm{I} 35$.

Tcherkézoff, Serge

2003 A Long and Unfortunate Voyage toward the Invention of the Melanesia/Polynesia Opposition (I 595-I832). Journal of Pacific History 38 (2): I75-I96.

2004 "First Contacts" in Polynesia: The Samoan Case (I722-I848): Western Misunderstandings about Sexuality and Divinity. Canberra: Journal of Pacific History Inc; Christchurch: Macmillan Brown Centre of Pacific Studies.

Teaiwa, Teresia

I994 bikinis and other s/pacific n/oceans. The Contemporary Pacific 6:87I09.

I999 Reading Gauguin's Noa Noa with Epeli Hau'ofa's Kisses in the Nederends: Militourism, Feminism, and the Polynesian Body. In Inside Out: Literature, Cultural Politics, and Identity in the New Pacific, edited by Vilsoni Hereniko and Rob Wilson, 249-263. Lanham, MD: Rowman \& Littlefield.

2005 Native Thoughts: A Pacific Studies Take on Cultural Studies and Diaspora. In Indigenous Diasporas and Dislocations, edited by Graham 
Harvey and Charles D Thomson, I 5-35. Burlington, vT: Ashgate Publishing Company.

Tengan, Ty P Kāwika

2008 Native Men Remade: Gender and Nation in Contemporary Hawai'i. Durham, nc: Duke University Press.

Thompson, Hunter S

I972 Fear and Loathing in Las Vegas: A Savage Journey to the Heart of the American Dream. New York: Random House.

Toop, David

I999 Exotica: Fabricated Soundscapes in a Real World. London: Serpent's Tail.

Trask, Haunani Kay

I993 From a Native Daughter: Colonialism and Sovereignty in Hawai'i. Monroe, ME: Common Courage Press.

Trinh, T Minh-ha

I99I When the Moon Waxes Red. New York: Routledge.

Underhill-Sem, Yvonne

2003 Marked Bodies in Marginalized Places: Understanding Rationalities in Global Discourses. Development: Journal of the Society for International Development 46 (2): I3-I7.

Wendt, Albert

I973 Sons for the Return Home. Auckland: Longman Paul.

I976 Towards a New Oceania. Mana I (I): 7 I-85.

Wolfe, Tom

I970 Radical Chic \& Mau-Mauing the Flak Catchers. New York: Bantam Books.

\section{Abstract}

In this article I draw examples from the broader terrain of academic and popular literature, news media, television, and film to explore questions regarding representations of Samoans, and especially Samoan men, in the United States. The mediated accessibility of Samoans, via televised sports and entertainment, combines with their relative geographic and demographic inaccessibility to produce popular images of a population that the vast majority of Americans know very little about. Such representations are gendered in particular ways, such that the archetypal Samoan body in US popular discourse is now masculine, rather than feminine. I discuss how popular representations of Samoan men may be similar to representations of black men-the latter so central to discourses of race in the United States-as well as how are they different, particularly in light of the discursively slippery histories of representing Pacific peoples as both noble and 
ignoble "savages." The main narrative component of discourses about Samoan men, body size, is critically engaged; additionally, the article argues that the added element of (indigenous) culture-thought to be outside or anterior to Western modernity—grant to Samoans an exoticness not normally granted to black Americans. This essay attempts to expose, engage, and examine these active processes of representation and myth creation-what visual theorist Clyde Taylor might term mythogenesis-to better understand the discursive terrain that Samoans negotiate, often ambivalently, in the United States.

KEYWORDS: Samoan, Pacific Islander, representation, masculinity, sports, stereotype, popular culture 